impulse could be felt or seen when the child cried. A percussion note could only be considered doubtful, if anything dull. There was considerable odema, with redness of the skin and subcutaneous tissues. The swelling (which I could not reduce) was also painful and the child cried lustily when touched. As there had been no vomiting or retching and the general condition of the child was good I prescribed an evaporating lotion and told the mother to put the little one to bed and to raise the buttocks on a pillow, as I thought that it might possibly be hydrocele of the cord. The next day there was a marked change for the worse. Vomiting had commenced and bloody mucus in small quantities was passed per anum. Without delay I had the child removed to the Eltham Cottage Hospital and at 5 P. M., after the administration of an anresthetic, I cut down on the swelling and found a very tight stricture at the upper end of the inguinal canal. When this was divided the gut slipped back into the abdomen; the colour of the intestine though dark was not black. I put in a few deep sutures of silk and closed the wound rapidly, as the patient's condition was becoming alarming. A collodion and antiseptic dressing was applied and the usual stimulants to combat shock were administered. The child rallied well, ceased to romit, and took the breast vigorously a few hours after operation. Convalescence was uninterrupted, and at the end of a fortnight the little patient was sent home, the wound having practically healed by first intention, and now after nine weeks there is only a fine scar with no bulging even on crying lustily.

I may add that immediately before operation the child was almost moribund, and I warned the parents that the chances were against his surviving the operation (the stricture having then lasted 39 hours and also considering the age of the patient). My best thanks are due to Mr. H. Sandford Smith, who administered the anæsthetic, and to the nursing staff of the Eltham Cottage Hospital for their assiduous care of the infant.

New Bitham.

\section{A NOTE ON THREE CASES ILLUSTRATING THE VALUE OF SUPRARENAL EXTRACT.}

By WALTER HENRY Brown, F.R.C.S. IREL.

CASE 1.-A man, aged 53 years, had been for the last 12 months suffering from profuse sweating following on an attack of nephritis. The sweating was so severe that latterly he had to change his clothing two or three times daily. He was passing only about six ounces of urine in the 24 hours. During the year he had lost two stones in weight. For the whole year he had been under treatment, but the sweating persisted and even increased. I put him on suprarenal tabloids. In two days the sweating began to subside and at the end of four days it had entirely ceased. Further, on the fourth day a normal quantity of urine was passed.

CASE 2.-A patient, aged 30 years, a "bleeder," suffered from hæmorwhoids. The bleeding was very severe, often soaking through his clothes, and he was beginning to suffer from the effects of the continuous drain. From the family history it did not seem to be a suitable case for operation, so I put him upon suprarenal extract, with the result that in a week's time the bleeding ceased and it has not yet returned.

CASE 3. - The patient, a woman, aged 36 years, had been much reduced by persistent hæmorrhage from a uterine myoma. Ergot and mineral acids had been tried without benefit; but within 48 hours of her taking suprarenal extract the bleeding ceased

I record these instances of the power of this animal extract in the hope that my experience may be of benefit to others. In the first case related the patient had becn examined by several medical men, but not one had seen such terrible distress in a man who was otherwise quite well. It is interesting to note that the quantity of urine passed increased as rapidly as the sweating diminished.

Leeds.

Somth Devon and East Cornwall Hospital.As a result of the recent Hospital Saturday in Plymouth the sum of $£ 563$ has been handed over to the South Devon and East Cornwail Hospital.

\section{A}

\section{HOSPITAL PRACTICE, B RITISH AND FOREIGN.}

Nulla autem est alia pro certo noscendi via, nisi quamplarimas et morborum et dissectionum historias, tum aliorum tum proprias collectas habere, et inter se comparare.-Mong $\mathbf{A N I}$ De Sed. et Caus. Morb., lib. iv., Procemium.

\section{GREAT NORTHERN CENTRAL HOSPITAL.}

A CASE OF EXTREME DILATATION OF THE LARGE INTESTINE NOT DUE TO STRICTURE, TERMINATING FATALLY.

(Under the care of Dr. H. W. Syers.)

THE rarity of idiopathic dilatation of the colon is very great Some of the cases certainly seem to be congenital in origin. while in another group the disease is apparently acquired. We have practically no knowledge of the etiology of the disease. One of the most striking examples of the disease was described by Dr. H. D. Rolleston and Mr. Warrington Haward. ${ }^{1}$ Early colotomy appears to be the only treatment likely to be of any use. In a case under the care of Dr. Osler ${ }^{2}$ recovery followed colotomy, but that case was congenital in origin.

In December, 1900, a carpenter, aged 59 years, presented himself in the out-patient room of the Great Northern Central Hospital giving a history of discomfort and distension after food during a period of many months. The abdomen was enormously distended and very tense. He was treated as an out-patient for a few days and then admitted to the ward. He had always been in good health until about 12 months before coming to the hospital. At that time he first noticed uneasy sensations after food and a feeling of fulness. He also observed that the abdomen was larger than was formerly the case. At this time he was much troubled with a frequent desire to defecate but without result; these efforts were attended with considerable straining. When the bowels acted the motions were loose, but no blood was passed, neither was the action accompanied by pain. The swelling of the abdomen gradually increased and he was able to work intermittently only. Six weeks before admission he was compelled to leave off work altogether. At this time the swelling sometimes became much less marked, but it always reappeared, the periods of improvement being of short duration only. He had not noticed that the symptoms were in any way influenced by the nature of the diet, and at no period of the jllness had he been troubled with vomiting. 'The patient's previous health had always been good with the exception that he suffered from acute rheumatism in 1871; he had not, however, experienced any further attack. He appeared to have been a free drinker, but there was no history of syphilis. The family history was altogether unimportant. On admission he was thin and wasted but of good colour. He was somewhat short of breath. There was no complaint of pain. The tongue was clean and the pulse and respiration were of normal frequency. The abdomen was uniformly and greatly distended, being also very tense. The percussion note was everywhere resonant and the liver dulness was altogether obliterated. There was no evidence of the presence of fluid in the peritoneal cavity. Over the back of the chest on the left side the abdominal resonance extended to the angle of the scapula; below this point the breath sounds were almost inaudible. 'The lungs were healthy at the apices and the heart sounds were normal. The specific gravity of the urine was 1016 ; it was acid and free from albumin. On rectal examination it was found that the anal orifice was drawn up and contracted, the rectum being greatly distended. There was no growth in this locality. The long rectal tube was passed and a very large quantity of gas escaped, its removal giving the patient much relief After the use of the long tube the abdomen was still distended, but less so than before the passage of the instrument. When the extreme distension was overcome

Transactions of the Clmical Society of London, vol. xxix., 1896 , p. 201 .

2 Archives of Pediatries, 1893, vol. x., p.3. 